\title{
Family chickens, poverty alleviation, food security and HIV/AIDS mitigation: The case of BONEPWA+
}

\author{
John Cassius Moreki \\ Department of Animal Science and Production, Botswana College of Agriculture, Gaborone, Botswana. \\ E-mail: jcmoreki@gmail.com. \\ Accepted 21 December, 2011
}

\begin{abstract}
This paper reviewed literature on the role of family chickens in poverty alleviation, food security and HIV/AIDS mitigation with particular reference to Botswana Network of People Living with HIV/AIDS (BONEPWA+). Family chickens play an important role in the nutrition and income generation of households in Botswana. Secondary sources of data collected from the family chicken project funded by the Swedish International Development Cooperation Agency (Sida) and currently implemented by BONEPWA+ were evaluated. The project supports vulnerable and disadvantaged groups such as homebased care patients and volunteers, out-of-school youths, widows/widowers, orphans and vulnerable children, female-headed households, people living with disabilities and those living with HIV/AIDS. Thirty-one project groups have been supported countrywide. This review highlights the contribution of family chickens to the livelihoods of people living with HIV/AIDS (PLWHA). A total of 750 PLWHA directly benefitted from the project while $\mathbf{4 5 0 0}$ indirectly benefited. Family chickens were consumed and sold to meet immediate family needs (e.g. the purchase of food and clothing), as well as to purchase other livestock (mainly goats) and building material. From October 2005 to September 2010, 6000 chickens were sold while $\mathbf{2 5 0}$ goats were purchased from the chicken proceeds. Money from chicken sales was also used to fund transport to health facilities for medical treatment, to pay school fees and to purchase school requisites for children. These data indicate that family chickens play an important role in food security, nutrition security, poverty alleviation, HIV/AIDS mitigation and economic empowerment of the vulnerable and disadvantaged members of the communities.
\end{abstract}

Key words: Family chickens, HIV/AIDS, moringa, PLWHA, selenium, small livestock.

\section{INTRODUCTION}

Botswana has one of the highest HIV/AIDS prevalence rates in the world (Botswana Institute for Development Policy Analysis, 2006). Figure 1 illustrates the HIV prevalence by districts in Botswana. On average, HIV prevalence for the districts is estimated to be $31 \%$. HIV prevalence is highest in the northern and eastern parts of Botswana (National AIDS Coordinating Agency, 2008). In each of the districts, HIV prevalence is higher among women than men. The HIV/AIDS epidemic has also resulted in increase in orphans

Botswana Network of People living with HIV and AIDS (BONEPWA+), which is a national network of people living with HIV and AIDS (PLWHA), was established in 2000 and has played a pivotal role in raising the status of family chickens (also referred to as village chickens). The
BONEPWA+ food security (chicken component) has resulted in the government designing Livestock Management and Infrastructure Development (LIMID) programme, which supports resource-poor farmers and youths to rear indigenous Tswana chickens and goats. Swedish International Development Corporation Agency (Sida) has supported a family chicken project in Botswana since 2005. According to BONEPWA+ (2010), the main objective of the Sida funded project is to contribute to improved farm productivity, income and nutrition among PLWHA.

The rearing of small livestock such as sheep, goats, poultry, guinea pigs and rabbits seems to be an effective HIV/AIDS mitigation strategy. In Botswana, Lesotho and Zambia, family chickens have been shown to play an 


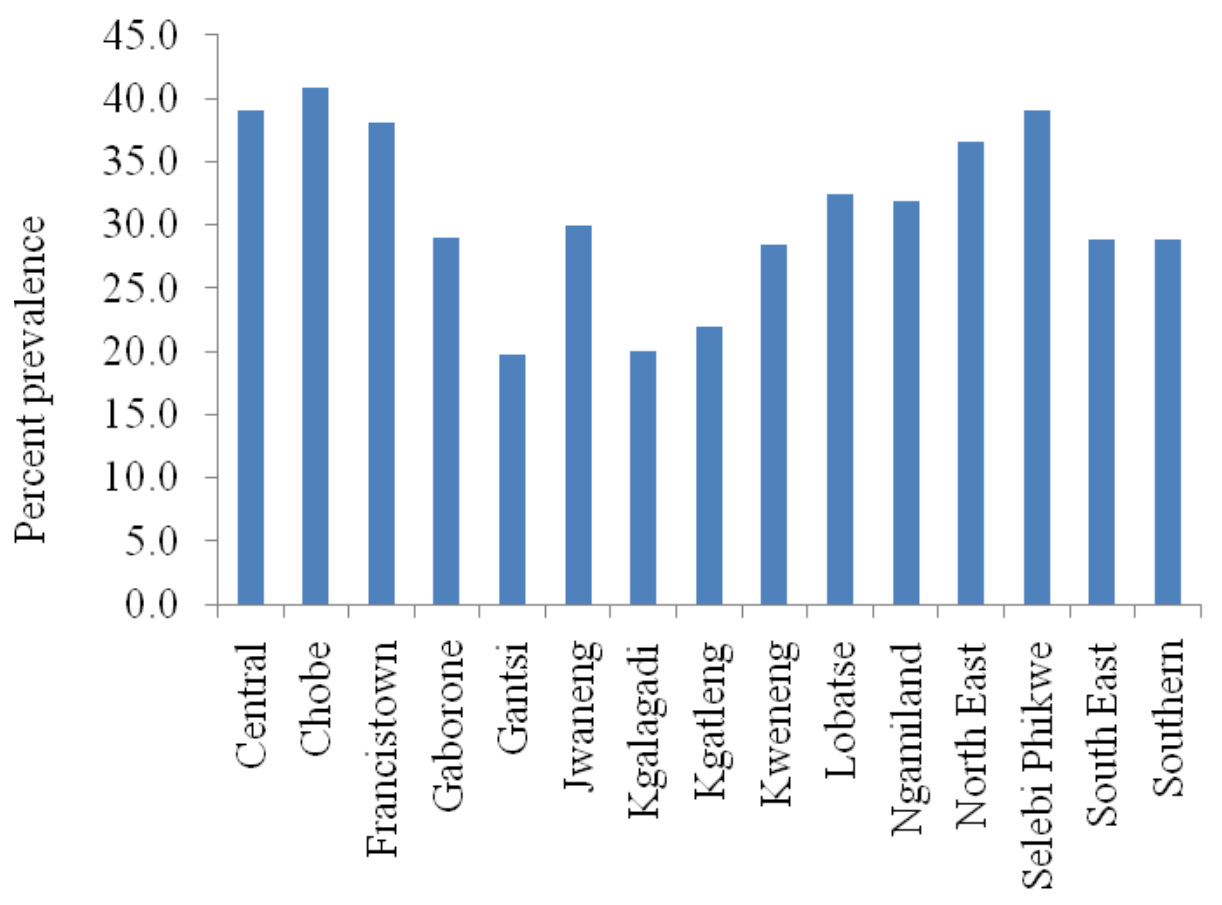

Districts

Figure 1. HIV prevalence by districts.

Source: Botswana Sentinel Surveillance (2009) cited by Ministry of Health (2009).

important role in households where there is a lack of able-bodied workers, such as households affected by HIV/AIDS or those that have a disabled family member. Simainga et al. (2011) reported that $79 \%$ of the respondents in Kalabo and Mongu districts of Zambia considered family poultry as one of the mitigation strategies against HIV/AIDS. According to Alders et al. (2005), in households headed by widows, children or grandparents, a chicken represents the easiest species to raise for sale and home consumption. This can provide a novel source of high quality protein and micronutrients, which play an important role in the nutrition of HIV/AIDS patients. Most of family poultry production is managed by women.

The contribution of family chickens to household food security, poverty alleviation, economic empowerment and HIV/AIDS mitigation in Botswana is scantily documented. Therefore, this review endeavours to highlight the contribution of family chickens to the livelihoods of PLWHA in Botswana.

\section{ROLE OF BONEPWA+ IN FAMILY POULTRY PRODUCTION}

BONEPWA+ is currently implementing a Sida funded food security and nutrition project aimed at contributing to improved household income, food security and nutrition through economic empowerment of PLWHA in Botswana.
The principal objective of the project is to promote family chickens, backyard gardens (vegetable production), and capacity building and mentoring of people that are infected and affected by HIV and AIDS. The project offers support to vulnerable and disadvantaged groups such as home-based care patients and volunteers, out of school youths, widows/widowers, orphans and vulnerable children, female headed households, people living with disabilities and PLWHA (BONEPWA+, 2009). The emphasis of this review is on the family chicken component of the food and nutrition security project.

According to BONEPWA+ (2010), the food security project covered 31 support groups involving 750 beneficiaries countrywide. Each beneficiary was given five indigenous Tswana chickens ( 1 cock and 4 point of lay hens) which served as breeding stock. It was thought that this flock size would be easy to manage by the rearers the majority of whom are rearing livestock for the first time. This sex ratio (1 cock to 4 hens) in this study is low compared to Cobb breeders (Cobb-Vantress Inc., 2008) that recommend 9-10 cocks per 100 hens. Therefore, the sex ratio in the present study is likely to result in underutilization of the cock. Compared to commercial chickens, Tswana chickens are hardy and can scavenge for feed; and hence are ideal for the village environment. In addition, British Lottery Fund supported family chicken projects in Maun and Tsabong, whereas Forum Syd supported a goat project in Bobonong 
(BONEPWA+, 2010). Recently, BONEPWA+ has started to provide incubation services to family chicken rearers in Maun, Radisele and Tsabong.

Each project beneficiary also received a moringa plant (Moringa oleifera) to ensure good health and nutrition of household recipients, as well as, as good health of the flock. Yang et al. (2006) reported that moringa added to fodder could be a potential bioceutical agent to substitute for antibiotics in livestock production. Furthermore, the workers showed that the consumption of moringa enhances the immune response of nutrient sufficient subjects. Also, consumption of nutrient and photochemicalrich vegetables, like moringa, leads to a better immune response compared to consumption of vegetables that are rich in fibre but lower in nutrient content such as cabbage.

Moringa has a range of medicinal uses with high nutriational value. Different parts of this plant contain a profile of important minerals, and are a good source of protein, vitamins, beta-carotene, amino acids and various phenolics (Anwar et al., 2007). In Uganda, Nalule et al. (2011) reported the use of moringa leaves in the control of helminthes in livestock. Moringa leaves and green fresh pods are used as vegetables by humans and are rich in carotene and ascorbic acid with a good profile of amino acids (Makkar and Becker, 1997).

The study of Kakengi et al. (2007) reported inclusion of $10 \%$ Moringa oleifera leaf meal (MOLM) in the diets for laying hens to be optimal and that an addition of MOLM above $10 \%$ required high energy based feeds for better utilization. Egg weight was higher when $10 \%$ MOLM was included in the diets for laying hens and decreased with levels above $10 \%$. The workers concluded that MOLM could completely replace sunflower seed cake up to $20 \%$ without any detrimental effect in laying chickens.

According to BONEPWA+ (2010), 750 PLWHA benefited directly from the project while 4500 people benefited indirectly. The people that benefited indirectly from the food security project are those that were donated chickens to, by project beneficiaries under the pass-on-gift model which is encouraged by BONEPWA+. According to the pass-on-gift model, project beneficiaries share the project benefits by donating some chickens to other vulnerable members of the communities within and outside their villages. This indicates that assistance to PLWHA is extended to an additional six people who are usually family members and/or relatives.

The majority of the project beneficiaries were females the majority of whom are caregivers and unemployed suggesting that the project is contributing to HIV/AIDS mitigation and economic empowerment. In order to reduce mortality in family chickens, BONEPWA+ provides vaccines and helps to administer them (vaccines). This indicates that BONEPWA+ is rendering extension service to the family chicken rearers. Moreki and Dikeme(2011) concluded that the effects of HIV and AIDS scourge at household level has reduced after beneficiaries started rearing family chickens since beneficiaries are now able to feed their households resulting in reduced dependency on government hand-outs, family members and relatives.

\section{The first rung on the livestock ladder}

Small livestock, especially family chickens, can provide the start of the owner climbing the "livestock ladder", leading to ownership of other livestock species such as goats and cattle (Dolberg, 2003). BONEPWA+ (2010) reported that rearing family chickens has resulted in beneficiaries owning other livestock such as goats, thus providing the start of the owners climbing the societal ladder. From October 2005 to October 2010, the beneficiaries of a Sida funded chicken project purchased 250 goats from the proceeds of chickens. In addition, a beneficiary in Bobonong reported having bought a cow from the chicken proceeds, whereas another beneficiary bought donkeys which are used for draught power and transport (BONEPWA+ 2010). This suggests that the rearing of chickens could enable rural families to start owning more valuable livestock such as goats and cattle, which are considered status symbols in most African countries including Botswana.

\section{Improved food security}

Nutrition is critically important to people receiving antiretroviral therapy, as malnourished HIV-infected people progress more quickly to AIDS. Some ways of improving the nutrition component of mitigation strategies include promoting block farming, school gardening, community kitchens for orphans and vulnerable children, home-based care nutrition support and nutrition campaigns and training (Economic Commission for Africa, 2006).

According to Disele et al. (2001), to prolong life PLWHA need adequate supply of protein for muscle building and body tissue maintenance; carbohydrates for energy and to prevent loss of weight and anorexia nervosa; and vitamins for body process regulation and boosting of the immune system, in particular vitamin C, A, the B-group, folic acid and minerals such as iron and zinc. Poor nutrition contributes to poor health, low labour productivity, low income, and livelihood insecurity. These factors put people, particularly women and girls, at risk of HIV infection as they are forced to migrate for waged labour or to engage in transactional sex work for income (Anon, 2006).

Food security projects in Botswana, Lesotho and Zambia have shown that family chickens play a crucial role in nutrition and food security among PLWHA. Rural Self-Help Development Agency (2011) in Lesotho reported that some people consider family chickens as an 
option to mitigate HIV and AIDS after realizing that chickens can be the easiest way of obtaining daily nutritional requirements. In their study in Botswana, Moreki et al. (2011a) reported that chickens provided relish and hence were the main supplier of good quality proteins (meat and eggs) to the households.

Eggs in particular offer a great nutritional bargain as they contain approximately 315 kilojoules and are an ideal protein source. Additionally, eggs supply an array of vitamins such as $A$ and $B_{12}$, and are one of the best food sources of vitamin $\mathrm{K}$, a bone-boosting nutrient. Also, eggs provide choline, a $\mathrm{B}$ vitamin that plays a role in brain development (Alders et al., 2003) and energy metabolism. Again, eggs are an ideal carrier for enriching human diets with important dietary minerals such as selenium and iodine. Selenium is required for the activity of the enzyme glutathione peroxidase - a key mediator of oxidant stress, other peroxidase enzymes (PHGHPX and $\mathrm{GSHx}-\mathrm{PI}$ ), and iodothyronine deiodinase (necessary for formation of triiodothyronine from thyroxine) (Patrick, 1999). Jacques (2006) states that selenium is involved in the proper functioning of the immune system or inhibiting the progression from HIV to AIDS.

The disease (AIDS) is reported to be less prevalent in countries with high selenium soil content than those with low selenium content. Selenium is required for sperm motility, and may reduce the risk of miscarriage. The conversion of thyroxine (T4) to the biologically active triiodothyronine (T3) also involves selenium. Stone et al. (2010) observed that numerous studies have reported low selenium status in HIV-infected individuals, and that serum selenium concentration declines with disease progression. Eggs and chicken meat are good sources of selenium.

\section{Income generation}

From October 2009 to September 2010, PLWHA sold 6000 chickens (BONEPWA+, 2010), indicating that 500 chickens were sold per month across the districts. Therefore, on average each beneficiary sold 0.67 chicken per month. Money obtained from sale of chickens was used to enhance the lives of PLWHA and their family members.

According to BONEPWA+ (2010), the majority of the patients said that they no longer defaulted from antiretroviral treatment after they started rearing family chickens as they were able to sell chickens to raise transport fares to health facilities for medical treatment. In addition, parents were able to purchase school requisites (uniforms, exercise books and pens) for their children, as well as to pay school fees (BONEPWA+, 2009, 2010).

In agreement with Moreki et al. (2010), chickens were sold to purchase smallstock (sheep and goats) that supplied beneficiaries and their families with meat and milk, which are good sources of selenium. Furthermore, proceeds from sale of chickens were also used to make improvements to beneficiaries' homes (e.g., painting or fitting new windows in a house) and/or to partly finance construction of a new hut or house. Beneficiaries also sold birds to buy vegetable seeds, building material, furniture, chicken feeds and to pay for weeding labour in arable fields. The use of money for weeding labour is particularly important for people with disabilities and/or those that are bedridden who cannot perform weeding tasks (BONEPWA+, 2009, 2010).

The purchase of goats is an important step for beneficiaries to start owning larger stock such as cattle. In addition, to meat production, goats also provide milk, which is an excellent source of selenium. BONEPWA+ (2009) reported that beneficiaries preferred tea with goat milk than cow milk. Project beneficiaries who are mainly women preferred to keep goats as they can be easily milked than cows. According to Lengkeek et al. (2008), PLHWA are less able to perform heavy work, to work for long periods or follow strict work schedules; there exists, therefore, the need to rear smallstock which are easy to keep as they require few inputs.

Egg consumption and sales among rearers appeared to be low as eggs are used mainly for hatching. However, egg consumption and sales are likely to be high during summer and rainy seasons because hatchability is low during these periods due to high ambient temperature and high relative humidity. As a result, rearers usually sell and consume eggs to reduce losses in summer.

\section{Technical support}

Technical support to the beneficiaries of the family chicken project is provided jointly by BONEPWA+ and the Ministry of Agriculture. However, due to the vastness of the country and inadequacy of resources (extension staff and transport) support is inadequate. According to BONEPWA+ (2010), 750 PLWHA were trained in general poultry management.

Fowl pox and NCD are some of the two common diseases that contribute to significant mortalities in family chickens in Botswana. Moreki et al. (2011b) reported the 10 common chicken diseases in Botswana in order of prevalence to be coccidiosis, fowl pox, salmonellosis, avian mycoplasma, colisepticaemia, nutritional deficiencies, pediculosis, E-coli, NCD and infectious bursal disease.

In order to reduce mortality, especially in chicks, 30000 chickens were vaccinated against Newcastle disease (NCD) and fowl pox using Lasota and fowl pox vaccines, and were also treated against internal and external parasites. In addition, BONEPWA+ supplied 500, 000 doses of vaccines (NCD and fowl pox) and 20 tonnes of sorghum bran and soya bean cake to the project beneficiaries for free.

A mixture of sorghum bran and soya bean cake was 
supplied and used as supplementary feeds to the birds.Also, 500 moringa (Moringa mellifera) seedlings were distributed to the beneficiaries across the country (BONEPWA +2010$)$. As indicated earlier, moringa has medicinal uses for both livestock and humans.

\section{CONCLUSION}

1. Family chickens contribute to income generation, improved nutrition and economic empowerment of the PLWHA.

2. The Sida funded food security project has laid the foundation for government and development agencies to help mitigate HIV/AIDS on support groups.

3. Technical support is inadequate. This calls for increased involvement of government extension service in family poultry production in order to reduce losses.

4. The effect of moringa on health management of family chickens needs investigation.

5. There is a need to evaluate the impact of the project on the lives of the beneficiaries.

\section{ACKNOWLEDGEMENT}

Thanks goes to Mr. Boitatolo Poroga from BONEPWA+ for his assistance with some relevant literature.

\section{REFERENCES}

Alders A, Bagnol B, Harun M, Young M (2005). Village poultry, food security and HIV/AIDS mitigation. Paper presented at the FAO meeting on HIV/AIDS and Livestock in Africa, Addis Ababa, Ethiopia, 8-10 March 2005.

Alders R, Cambaza AB, Harun M (2003).Village chickens, food security and HIV/AIDS mitigation. Retrieved from www.kyeemafoundation.org/content/.../HIVAIDS\%20paper\%20Nov03 .pdf

Anon (2006) HIV/AIDS, Gender, and Household Food Security: The Rural Dimension. www.icad-cisd.com

Anwar F, Latif S, Ashraf M, Gilani AH (2007). Moringa oleifera: a food plant with multiple medicinal uses. Phytother. Res., 21:17-25.

BONEPWA+ (Botswana Network of People living with HIV and AIDS) (2009). Annual Technical Report: Village chicken component. Gaborone, Botswana.

BONEPWA+ (Botswana Network of People living with HIV and AIDS) (2010). Annual Technical Report: Village chicken component. Gaborone, Botswana.

Botswana Institute for Development Policy Analysis, (2006). Prospects for Export Diversification in Botswana. Gaborone, Botswana.

Cobb-Vantress Inc. (2008). Cobb Breeder Management Guide. December 15, 2008. Arkansas, USA. p 38.

Disele PLP, Peters S, Masoloko T, Shumba A (2001). Nutrition and the ailing immune system: a challenge in the new millennium. Pula: Botswana J. Afr. Stud. 15(2): 2253-258.

Economic Commission for Africa (2006). Mitigating the impact of HIV/AIDS on smallholder agriculture, food security and rural livelihoods in Southern Africa: Challenges and action plan. Retrieved from

AIDSandAgriculture.pdf
Jacques KA (2006). Zoonotic disease: Not just from birds, not just in the flu. In: TP Lyons, KA, Jacques and JM Hower (eds.), Nutritional Biotechnology in the Feed and Food Industries: Proceedings of Alltech's $22^{\text {nd }}$ Annual Symposium, Lexington, Kentucky, USA. pp. 23 26 April 2006. Nottingham University Press, UK. pp. 149-159.

Kakengi AMV, Kaijage JT, Sarwatt SV, Mutayoba SK, Shem MN Fujihara T (2007). Effect of Moringa oleifera leaf meal as a substitute for sunflower seed meal on performance of laying hens in Tanzania. Livest. Res. Rural Dev. 19(8).

Lengkeek A, Koster M, Salm M (2008). Mitigating the effects of HIV/AIDS in small-scale farming. Agromisa Foundation, Wageningen. ISBN Agromisa: 978-90-8573-13 090-3. Retrieved from http://www.anancy.net/documents/fileen/Agrodok-45Mitigating_the_effects_of_HIV_AIDs_in_small-scale_farming.pdf

Makkar HPS, Becker K (1997). Nutrient and anti quality factors on different morphological parts of the Moringa tree. J. Agri. Sci. 128: 31.

Ministry of Health (2009). Botswana Second Generation HIV Antenatal Sentinel Surveillance Technical Report. Gaborone. pp. 84.

Moreki JC, Dikeme R, Poroga B (2010). The role of village poultry in food security and HIV/AIDS mitigation in Chobe District of Botswana. Livest. Res. Rural Dev. 22(3). Retrieved from http://www.Irrd.org//rrd22/3/more22055.htm

Moreki JC, Poroga B, Dikeme R (2011a). Strengthening HIV/AIDS food security mitigation mechanisms through village poultry. Livest. Res. Rural Dev. 23(2).

Moreki JC, Chiripasi SC, Montsho T, Chibua R, Gabanakgosi K (2011b). Prevalence of poultry diseases and parasites in Botswana. Online J. Anim. Feed Res. 1(5):214-217.

Moreki JC, Dikeme R (2011). Small livestock, food security, nutrition security and HIV/AIDS mitigation. Retrieved 16 December 2011 from www.intechopen.com/download/pdf/pdfs_id/22357

Nalule AS, Mbaria JM, Olila D, Kimenju JW (2011). Ethnopharmacological practices in management of livestock helminthes by pastoral communities in the drylands of Uganda. Livest. Res. Rural Dev. 23(2).

National AIDS Coordinating Agency (2008). Progress Report of the National Response to the UNGASS Declaration of Commitment on HIV/AIDS.

Patrick L (1999). Nutrients and HIV: Part One - Beta Carotene and Selenium. Altern. Med. Rev., 4(6): 403-413.

Rural Self-Help Development Agency (2011). The study on socioeconomic status of village chickens at $\mathrm{Ha}$ Molemane (Berea), Phamong (Mohales' Hoek), Tebang, Ha Notsi, and Ribaneng (Mafeteng) of Lesotho. Maseru, Lesotho. p 111.

Simainga S, Moreki JC, Banda F, Sakuya N (2011). Socio-economic study of family poultry in Mongu and Kalabo Districts of Zambia. Livest. Res. Rural Dev. 23(2).

Stone CA, Kawai K, Kupka R, Fawzi WW (2010). Role of selenium in HIV infection. Nutr. Rev. 68(11):671-681.

Yang Ray-Lu, Chang Lien-Chung, Hsu Jenn-Chung, Weng BBC, Palada MC, Chadha ML, Levasseur V (2006). Nutritional and functional properties of Moringa leaves - from germplasm, to plant, to food, to health. Moringa and other highly nutritious plant resources: Strategies, standards and markets for a better impact on nutrition in Africa. Accra, Ghana, November 16-18, 2006. 